\title{
Examining the benefits of using bio-CNG in urban bus operations
}

\author{
Fearghal Ryan ${ }^{1}$ \\ Brian Caulfield ${ }^{2} *$ \\ ${ }^{1}$ Engineering, Science \& Technology Entrepreneurship \\ University of Notre Dame \\ ${ }^{2}$ Department of Civil, Structural and Environmental Engineering \\ Trinity College Dublin
}

Keywords: alternative fuel, bus operations, compressed natural gas

\begin{abstract}
Public service fleets offer an attractive option for introducing new renewable fuels on a large scale, which allow for the reduction of both greenhouse gas emissions and exhaust air pollutants. This study examines the use of biomethane (bio-CNG) and compressed natural gas $(\mathrm{CNG})$ for part of the bus fleet in Dublin, Ireland. The emissions produced from the 2008 fleet based at one of the city's seven bus depots were compared to use of new diesel and bio-CNG buses, which were modelled using COPERT 4. The optimum feedstock for bio-CNG production in Ireland was then investigated, as well as the quantity of feedstock needed to produce the required bioCNG to fuel the bus fleet examined. As expected the results showed a substantial decrease in all exhaust emissions from the use of bio-CNG buses compared the 2008 fleet. Grass silage was chosen as the optimum feedstock for production of bio-CNG in Ireland.
\end{abstract}

\section{Introduction}

In 2004, the Irish government launched a pilot scheme for excise relief on biofuels (Sustainable Energy Ireland, 2005). The aim of the scheme was to stimulate the initial development of a biofuel market and concerned the production of pure plant oil, biodiesel and bioethanol in approved pilot projects. The scheme was subject to a maximum production capacity of 8 million litres per annum of biofuel, and was valued at $€ 3$ million. More recently, the Department of Transport has instructed public transport operators to move to a 5\% biodiesel blend in the current fleet, and this is expected to be implemented in 2009 (DCENR, 2008). The Department of Transport has also instructed public transport operators to ensure that all new buses, as part of future fleet replacement, can operate on a $30 \%$ biodiesel blend. This paper examines the potential benefits of switching 81 buses in the Dublin bus fleet to alternative fuels. Currently, Dublin Bus operates a fleet of 1,008 buses (Dublin Bus, 2009). This paper uses COPERT 4, an emissions model, to estimate the reductions in green house gas emissions and air pollutants from introducing alternative fuels to the Dublin Bus fleet. The Euro standards referred to in this paper relate to a rating given to buses to measure how efficient the buses are in terms of emissions. These standards are set by the European Union and classify vehicles in accordance with their emissions.

\footnotetext{
* Corresponding author Email: brian.caulfield@tcd.ie
} 
Several studies have explored the benefits of bio-CNG. Karlström (2005) completed a study which expressed the local air pollution benefits in monetary terms from hydrogen fuel cell buses, CNG buses and Euro V diesel buses. Euro V standard is the current mandatory limit for new buses purchased in the European Union. This study presented a quantitative assessment of the local environmental benefits of using each type of bus along a central bus route in Götenburg. Euro II diesel buses were used as a reference scenario. The author found that the present local environmental benefits for a hydrogen fuel cell bus are much smaller than the annualised purchase cost, although the local monetary benefits would be meaningful to consider if compared with the incremental costs of a mass-produced fuel cell bus. Schimek (1998) examined the bus fleets in New York City, Los Angeles, Chicago and Boston to ascertain how moving to alternative fuels could reduce $\mathrm{PM}$ and $\mathrm{NO}_{\mathrm{x}}$ emissions. The results of this study suggest that increasing the turnover of diesel fleets could produce more rapid emissions reductions. The author suggests that the little difference in the cost of CNG relative to diesel, and the shorter range of $\mathrm{CNG}$ vehicles, explains why CNG fuelled buses haven't been adopted, on a larger scale. Clark et al. (2006) examined the use of CNG and hybrid electric buses in Mexico City. The results of this study suggest that while hybrid electric buses produced significant fuel economy, while CNG buses had the lowest PM emissions.

\section{Methodology}

In order to calculate the quantity of emissions produced by the fleet examined, it was necessary to obtain the necessary input data for the COPERT model. Table 1 details the bus fleet modelled in this paper including Euro level, the number of kilometres travelled, and the number of kilometres travelled per-bus. An average speed of 13 $\mathrm{km} / \mathrm{hr}$ was assumed. Four different models are estimated in this paper. The first model measures the status quo; the second model assumes that the current fleet is replaced with Euro $\mathrm{V}$ buses. The third model assumes that the bus fleet is replaced with Enhanced Environmental Vehicle (EEV - voluntary extra low emission limits introduced by the European Commission in 1999) buses that run on CNG. The final model assumes that the fleet is replaced with EEV buses which run on bio-CNG. Apart from the figure for $\mathrm{CO}_{2}$, all results for the fourth model are the same as those for the third model. The long-term $\mathrm{CO}_{2}$ value is taken as $40 \%$ of the tailpipe $\mathrm{CO}_{2}$ given by COPERT. The mileage used for the three alternative scenarios was based on the weighted average of the mileage in model 1.

\begin{tabular}{|c|c|c|c|c|}
\hline Model & Subsector & Technology & Number of buses & Mileage $(\mathrm{km} /$ year $)$ \\
\hline \multirow[t]{3}{*}{1} & Urban standard $15 \mathrm{t}$ bus & HD Euro II $-91 / 542 / E E C$ standards & 38 & 59,293 \\
\hline & Urban standard $15 \mathrm{t}$ bus & HD Euro III - 2000 standards & 28 & 72,161 \\
\hline & Urban standard $15 \mathrm{t}$ bus & HD Euro IV - 2005 standards & 15 & 87.754 \\
\hline 2 & Urban standard $15 \mathrm{t}$ bus & HD Euro V - 2008 standards & 81 & 69,012 \\
\hline 3 & Urban CNG buses ( $15 \mathrm{t}$ ) & EEV & 81 & 69,012 \\
\hline 4 & Urban bio-CNG buses (15t) & EEV & 81 & 69,012 \\
\hline
\end{tabular}

The greenhouse gases which are considered in this paper are Carbon dioxide $\left(\mathrm{CO}_{2}\right)$, methane $\left(\mathrm{CH}_{4}\right)$ and nitrous oxide $\left(\mathrm{N}_{2} \mathrm{O}\right)$, which can each be described in the form of carbon dioxide equivalents $\left(\mathrm{CO}_{2 \mathrm{e}}\right)$, where $\mathrm{CO}_{2}$ is given the value of $1 \mathrm{CO}_{2 \mathrm{e}}$ (IPCC, 
2007). The actual weighting used to convert $\mathrm{CH}_{4}$ and $\mathrm{N}_{2} \mathrm{O}$ to $\mathrm{CO}_{2 \mathrm{e}}$ depends on the particular global warming potential lifetime used. For this study it was taken as 100 years, and as such $\mathrm{CH}_{4}$ and $\mathrm{N}_{2} \mathrm{O}$ assumed weightings of 25 and 298 respectively (IPCC, 2007).

Despite there being an advanced fuel specification provided by the COPERT 4 model for 2005 and 2009 stage fuel. This differs slightly from the values which are currently used in Ireland, which are defined in the Air Pollution Act 1987 (Irish Statute Book, 2007). The only difference between the 2005 and 2009 stage fuel used in Ireland is that the new fuel is almost sulphur free, having its sulphur level reduced from 50 parts per million (ppm) to $10 \mathrm{ppm}$.

The cetane number is a key fuel property of diesel and is a measure of a fuel's ignition delay. In a diesel engine, higher cetane fuels will have shorter ignition delay periods than lower cetane fuels. This allows more time for the fuel combustion process to be completed, which leads to better combustion and reduced particulate emissions at the tailpipe. The minimum cetane number specified by EN 590 is 46, while the standard range that allows diesel engines to run efficiently is 40-55. After the maximum value of 55, the fuel's performance hits a plateau and does not improve further. The carbon neutrality of bio-CNG from grass silage was taken as $60 \%$. As there is no single answer for the carbon neutrality of bio-CNG due to the number of variables involved, an average figure of $60 \%$ was used. Variables include the source of heat and electricity used in the process, the fertilizer replacement by grass digestate, carbon sequestered and efficiency of the vehicle.

\section{Results and analysis}

\subsection{Emissions modelling}

Four emissions models were estimated in this study. Table 2 presents the results of the estimated emissions from each of the four models estimated over a one year period. The results show that each of the alternatives examined would realise a significant reduction in air pollutants. The findings show that the bus operator could realise a $64 \%$ reduction in $\mathrm{CO}_{2}$ emissions from changing the fleet to EEV buses fuelled with bio-CNG. Models 3 and 4 show a 71\% reduction in $\mathrm{CO}$ emissions compared to the results from the base model. It was estimated that by changing the fleet to Euro $\mathrm{V}$ vehicles there would be an $89 \%$ reduction in CO emissions. The results for models 3 and 4 suggest an $87 \%$ reduction in $\mathrm{PM}_{2.5}$ emissions and a $77 \%$ reduction in $\mathrm{PM}_{10}$. The results for model 3 also showed a considerable reduction of $60 \%$ in $\mathrm{PM}_{2.5}$ emissions and $53 \%$ in $\mathrm{PM}_{10}$ levels. $\mathrm{NO}_{\mathrm{x}}$ emissions were also shown to decrease by $87 \%$ for models 3 and 4 and by $65 \%$ for model 2 .

Overall the alternative bus fleets modelled demonstrates a considerable saving in terms of emissions. A comparison between the three alternatives examined demonstrates that the bus fleet operated using bio-CNG (model 4) would result in the largest decrease in overall emissions. 


\begin{tabular}{|c|c|c|c|c|c|c|c|c|}
\hline Pollutant & Model 1 & $\%$ & Model 2 & \% Change from model 1 & Model 3 & $\%$ Change from model 1 & Model 4 & $\%$ Change from model 1 \\
\hline $\mathrm{CO}_{2}$ & 7861 & 100 & 7689 & -2 & 7022 & -11 & 2809 & -64 \\
\hline $\mathrm{N}_{2} \mathrm{O}$ & 0.044 & 100 & 0.181 & 311 & 0 & -100 & 0 & -100 \\
\hline $\mathrm{co}$ & 19.45 & 100 & 2.23 & -89 & 5.59 & -71 & 5.59 & -71 \\
\hline voc & 3.45 & 100 & 0.24 & -93 & 5.59 & +62 & 5.59 & +62 \\
\hline $\mathrm{SO}_{2}$ & 0.249 & 100 & 0.244 & -2 & 0 & -100 & 0 & -100 \\
\hline $\mathrm{NO}_{x}$ & 82.02 & 100 & 28.65 & -65 & 13.97 & -83 & 13.97 & -83 \\
\hline $\mathrm{NO}_{2}$ & 10.37 & 100 & 2.87 & -72 & 0 & -100 & 0 & -100 \\
\hline $\mathrm{PM}_{2.5}$ & 1.667 & 100 & 0.671 & -60 & 0.221 & -87 & 0.221 & -87 \\
\hline $\mathrm{PM}_{10}$ & 1.879 & 100 & 0.883 & -53 & 0.432 & -77 & 0.432 & -77 \\
\hline
\end{tabular}

Note: All values for pollutants are in metric tonnes.

In order to assess the accuracy of COPERT modelling, the modelled emissions of $\mathrm{CO}_{2}$ for the original fleet $(7,861 \mathrm{t})$ was compared to the actual $\mathrm{CO}_{2}$ emitted from the 2008 fleet. This was found using the range of 1400-1450 grams of $\mathrm{CO}_{2}$ per kilometre. The margins of error for the COPERT figures compared to the actual were found to be $0.45 \%,-1.31 \%$ and $-3.01 \%$ for the values of $1400 \mathrm{~g} / \mathrm{km}, 1425 \mathrm{~g} / \mathrm{km} \mathrm{\&} 1450 \mathrm{~g} / \mathrm{km}$ respectively.

\subsection{Feedstock calculation}

It was necessary to carry out a sensitivity analysis for the grass silage land area calculation as it was not possible to obtain values for the energy contents of the diesel and CNG used in the COPERT modelling. The sensitivity analysis for the production of the bio-CNG for the bus fleet examined was based on two separate methods, CNG and diesel calculations. The CNG calculation had one variable, the fuel's energy density $(\mathrm{GJ} / \mathrm{t})$, while the diesel calculation had two, the quantity of diesel used and its energy density. The CNG fleet would require 2543.44 tonnes; the EURO II-III-IV fleet would require 2494.37 tonnes and the EURO V fleet 2439.86 tonnes.

The values used for the energy density of natural gas in the CNG method were based on the Higher Heating Values (HHV) of three different references, and gave the likely range of values that could have been used in COPERT. The numbers $1,2 \& 3$ from Table 3 correspond to the values presented in Emerald Energy (2009), British Gas (1990) and ACEA (2009) respectively. All three figures were given as higher heating value (HHV) figures, with the lower heating value (LHV) figures, which apply to the natural gas engine, being taken as $90 \%$ of the HHV. The mid range LHV value, corresponding to number " 2 ", was used as it was close to the mean of the three values.

In order to calculate the land area need the energy required was calculated in terms of the volume of methane $\left(\mathrm{m}^{3} / \mathrm{a}\right)$. This was found using the energy required (GJ/a) and the energy density of methane $\left(37.78 \mathrm{MJ} / \mathrm{m}^{3}\right)$. The mass of silage figure assumes a biogas yield of $123 \mathrm{~m}^{3} / \mathrm{t}$ of silage and a silage yield of $60 \mathrm{t} / \mathrm{ha}$ of land (Murphy and Power, 2008). Finally, the Life Cycle Analysis (LCA) Land area accounted for a parasitic energy demand during production of $42 \%$ (Smyth et.al 2009). 
Table 3

Land area calculation using energy density of CNC.

\begin{tabular}{|c|c|c|c|c|c|c|}
\hline \multirow{4}{*}{$\begin{array}{l}\mathrm{CNG}(\mathrm{t} / \mathrm{a}) \\
\text { Energy density }(\mathrm{GJ} / \mathrm{t})\end{array}$} & \multicolumn{6}{|l|}{2543.44} \\
\hline & \multicolumn{3}{|l|}{$\mathrm{HHV}$} & \multicolumn{3}{|l|}{ L.HV } \\
\hline & 1 & 2 & 3 & - & - & - \\
\hline & 55.6 & 52.41 & 50.3 & 50.04 & 47.169 & 45.27 \\
\hline Energy required (GJ/a) & 141,415 & 133,302 & 127,935 & 127,274 & 119,972 & 115,142 \\
\hline As methane $\left(\mathrm{CH}_{4}-\mathrm{m}^{3} / \mathrm{a}\right)$ & 3743,125 & 3528,367 & $3,386,316$ & $3,368,813$ & $3,175,530$ & $3,047,685$ \\
\hline As bio-CNG $\left(97 \% \mathrm{CH}_{4}\right)$ & 3858,892 & 3637,491 & $3,491,048$ & $3,473,003$ & $3,273,742$ & $3,141,943$ \\
\hline As biogas $\left(55 \% \mathrm{CH}_{4}\right)$ & 6805,682 & 6415,212 & $6,156,939$ & $6,125,114$ & $5,773,691$ & $5,541,245$ \\
\hline Mass of silage $(\mathrm{t} / \mathrm{a})$ & 55,331 & 52,156 & 50,056 & 49,798 & 46,941 & 45,051 \\
\hline Land area (ha) & 922 & 869 & 834 & 830 & 782 & 751 \\
\hline LCA land area (ha) & 1590 & 1499 & 1438 & 1431 & 1349 & 1295 \\
\hline
\end{tabular}

The diesel based calculation gave slightly lower results compared to the CNG calculations. This could be attributed to the higher efficiency of diesel engines compared to CNG. The first variable in the diesel sensitivity analysis was the mass of diesel combusted, i.e. the quantity used by the 2008 Euro II-III-IV fleet or by the new fleet of Euro V buses. In order to partly account for the lower CNG engine efficiency, the quantity of diesel used by the less efficient Euro II-II-IV was taken to be the more accurate value.

The second variable was the energy density of the diesel. Due to the smaller variation in energy contents of diesel compare to $\mathrm{CNG}$, two values were used in the sensitivity analysis. These correspond to the number "4" (ACEA, 2009), which was assumed to be the more accurate, and the number " 5 ", which was used in a similar calculation in "An argument for using biomethane generated from grass as a biofuel in Ireland" (Murphy and Browne, 2008).

The first step of land area calculation using diesel was to convert the quantity of diesel required from mass to volume using the density of $845 \mathrm{~kg} / \mathrm{m}^{3}$, and then to the energy required using the energy density of diesel. The two values which were assumed to be the most accurate were 1,349 ha and 1,224 ha, corresponding to "LHV 2" and "Euro II-III-IV 4" respectively. The values were reasonably close, with the diesel value $9.3 \%$ lower. The lowest value obtained was approximately $74 \%$ of the maximum value (see Table 4).

Table 4

Land area calculation using quantity and energy density of diesel.

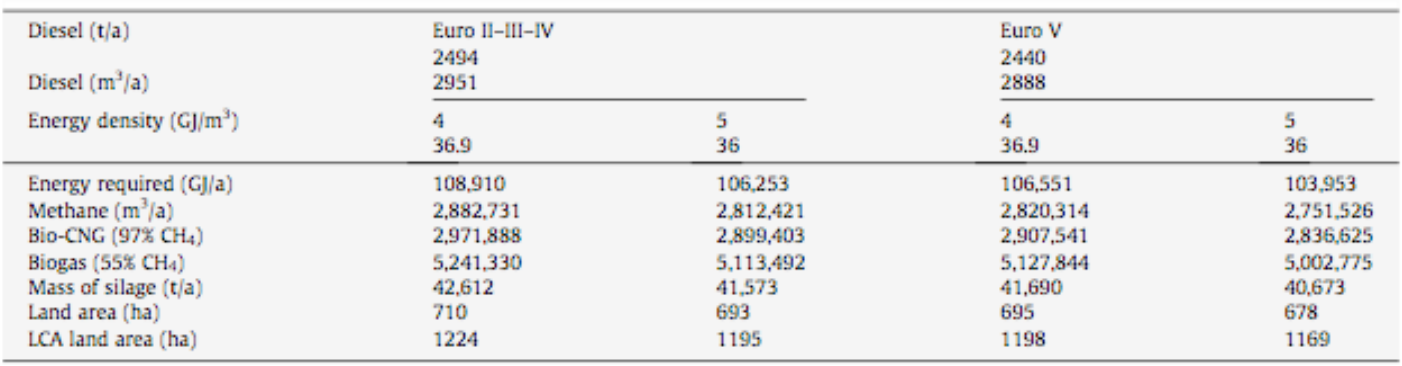

\section{Conclusions}

The results showed a major decrease in all pollutants from the use of CNG EEV buses compared to the 2008 fleet for Euro II, III and IV buses. There was a minimum reduction of $70 \%$ in emissions of all air pollutants, and a $100 \%$ reduction in $\mathrm{SO}_{2}$ and heavy metal emissions due to the fuel used. There was a decrease of $63 \%$ in the emission of greenhouse gases when bio-CNG was used instead of CNG. CNG showed a $7 \%$ reduction in $\mathrm{CO}_{2 \mathrm{e}}$ emissions. When the use of $\mathrm{CNG}$ and bio-CNG was compared to a new fleet of 81 Euro $\mathrm{V}$ diesel buses, there was still a significant reduction in the 
emission of most air pollutants, with $\mathrm{NO}_{\mathrm{x}}$ and $\mathrm{PM}$ emissions down by a minimum of $50 \%$. The two exceptions to this were $\mathrm{CO}$, which a showed a major increase, and NMVOC, which showed a small increase. This validates the view that the gap between the air pollution emissions of natural gas buses and diesel buses has narrowed with an improvement in technology, and in some cases, such as for $\mathrm{CO}$ and NMVOC, diesel is preferable. The use of Euro V diesel buses showed only a very small decrease in greenhouse gas emissions of $2.3 \%$ compared to the 2008 fleet. This confirms the fact that improvements in bus engine technology will not be significant enough to help Ireland reduce its greenhouse gas emissions.

\section{Acknowledgements}

The authors would like to thank Dublin Bus for providing the vehicle activity data. The authors would like to thank the referees sincerely for their helpful suggestions to improve the original manuscript

\section{References}

Sustainable Energy Ireland. Policy Incentive Options for Liquid Biofuels Development in Ireland. 2005. Dublin.

DCENR (The Department of Communications, Energy and Natural Resources). Report on measures taken to promote the use of biofuels or other renewable fuels to replace diesel or petrol - Compliance with Directive 2003/30/EC (Article 4). 2008. Dublin.

Dublin Bus. http://www.dublinbus.ie/en/About-Us/Dublin-Bus-Fleet/ . Accessed July $1^{\text {st }}, 2009$.

Karlström, M. Local environmental benefits of fuel cell buses - a case study. Journal of Cleaner Production, 13, 2005, pp 679-685.

Schimek, P. Reducing particulate matter and oxides of nitrogen emissions from heavy duty vehicles - The urban bus case. In Transportation Research Record: Journal of the Transportation Research Board, No. 1641, Transportation Research Board of the National Academies, Washington, D.C., 1998, pp. 39-47.

Clark. N. N., Borrell, E. R., McKain, D.L., Paramo, V. H., Wayne, W.S., Vergara, W., Barnett, R. A., Gautam, M., Thompson, G., Lyons, D. W., Schipper, L. Evaluation of emissions from new and in-use transit buses in Mexico City, Mexico. In Transportation Research Record: Journal of the Transportation Research Board, No. 1987, Transportation Research Board of the National Academies, Washington, D.C., 2006, pp. 42-53.

Murphy, J.D., Power, N.M. An argument for using biomethane generated from grass as a biofuel in Ireland. Biomass and Bioenergy, doi:10.1016/j.biombioe.2008.08.018

IPCC (Intergovernmental Panel on Climate Change). Fourth Assessment Report: The Physical Science Basis. Contribution of Working Group I to the Fourth Assessment Report of the IPCC. Geneva. ISBN 978 0521 88009-1. 2007. 
Irish Statute Book. S.I. No. 541/2003. Air Pollution Act, 1987 (Environmental specification for Petrol and Diesel fuels) Regulations 2003. Stationery Office, 2003. Dublin.

Emerald Energy. Efficiency of condensing boilers. April. Available from: http://www.emeraldenergy.ie/info/boiler-efficiency.htm, Accessed March 18, 2009.

British Gas. Combustion engineering and gas utilisation. Taylor \& Francis; $3^{\text {rd }}$ edition, December 31, 1990

ACEA. What are the main differences between diesel and petrol? http://www.acea.be/index.php/news/news_detail/what_are the_main_differences_bet ween_diesel_and_petrol/, Accessed February 24, 2009.

Smyth, B.M., Murphy, J.D., O'Brien, C.M. What is the energy balance of grass biomethane in Ireland and other temperate northern European climates? Renewable and Sustainable Energy Reviews 13. 2009. pp 2349-2360 